\title{
Influence factors analysis of farmers' participation in agricultural machinery cooperative management
}

\author{
Baodan Yin ${ }^{1}$ \\ 1.Coll Mech \& Elect Engn, NW A\&F Univ \\ Yangling, China \\ lilikg2004@163.com
}

\author{
Yuxiang Huang $1,2 *$ \\ 1.Coll Mech \& Elect Engn, NW A\&F Univ \\ 2.China Research Center for Agricultural \\ Mechanization Development, China Agri Univ \\ Yangling; Beijing, China \\ hyx@nwsuaf.edu.cn \\ * Corresponding Author
}

\author{
Wei $\mathrm{Li}^{1}$ \\ 1.Coll Mech \& Elect Engn, NW A\&F Univ \\ Yangling, China \\ williamlee190@163.com \\ Ruixiang $\mathrm{Zhu}^{1}$ \\ 1.Coll Mech \& Elect Engn, NW A\&F Univ \\ Yangling, China \\ jdxy9223@nwsuaf.edu.cn
}

\begin{abstract}
Agricultural machinery cooperative management contributes to effective integration of capital, technology, equipment, information, talents and other production factors. Besides, it is an important way to improve the utilization rate of agricultural machinery and increase household income. In this study, 154 households are surveyed as research samples. On the basis of binary logistic model, participation behavior of farmers and relevant influence factors are analyzed in agricultural machinery cooperative management. The results indicate that significant influence factors of farmers' participation in agricultural machinery cooperative management include whether farmers know of agricultural machinery cooperation, operation training experience of agricultural machinery, the proportion of agricultural income in total household income, participation cost of agricultural machinery cooperation, the proportion of neighbors joining agricultural machinery cooperation in all the neighbors, degree of government support, and level of satisfaction with agricultural machinery management.
\end{abstract}

Keywords-agricultural machinery; management; influence factors; logistic model

cooperative

\section{INTRODUCTION}

The development of agricultural machinery cooperation has become an effective way to improve utilization efficiency and benefit of farm machinery, and it plays an significant role in enhancing social service level of agricultural machinery and promoting the development of agricultural mechanization ${ }^{[1-2]}$. Farmer household' decision-making behavior in agricultural production activities is a dynamic process with various interactive factors, and any one new added element is likely to have a important impact on farmers' investment behavior in agricultural production. Professional farmers always treat agricultural production decisions rationally, and they will decide whether to participate in cooperative organization based on expected benefits \& costs, and their own conditions $^{[3]}$. Only when farmers believe they can make more money from cooperative organizations, will they choose to establish or join in agricultural machinery cooperation.

As a special kind of professional farmer cooperatives, the members of agricultural machinery service organization pursuit organizational benefit along with their self-interest achievement and self-value realization, therefore teamwork among members is not completely a cooperation for mutual interest ${ }^{[5]}$. There exists few research in system analysis of farmers' participation by empirical analysis in agricultural machinery cooperative management ${ }^{[5-6]}$.

Therefore, this paper surveys 154 households, analyze farmers' participation in agricultural machinery cooperative management and corresponding influence factors based on binary logistic model, and aim to provide measures and suggestions for the development of agricultural machinery cooperation while analyzing agricultural machinery cooperative management of farmers.

II. THEORETICAL ANALYSIS, RESEARCH HYPOTHESIS AND DATA SOURCES

\section{A. Logistic model}

In this paper, binary logistic model is used to study farmers' participation in agricultural machinery cooperative management and related influence factors. Farmers' choice of agricultural machinery cooperative management can be divided into two kinds: willing to join and unwilling to do. This decision is treated as a typical binary decision variable and belongs to an individual micro-decision problem for the farmers. The logistic 
model is the most frequently used model to analyze technology adoption process, and it has always been applied to technology adoption of micro individuals and its influence factors analysis ${ }^{[7-8]}$. The choice to join agricultural machinery cooperative management is assigned a value of 1 , while the decision not to join is assigned a value of 0 . Assuming $x_{1}, x_{2}, \cdots, x_{k i}$ are a series of factors influencing farmers' choice of agricultural machinery cooperative management, the logistic regression model can be formulated as:

$$
P_{i}=F\left(\alpha+\sum_{j=1}^{k} \beta_{j} x_{j}\right)=1 /\left\{1+\exp \left[-\left(\alpha+\sum_{j-1}^{k} \beta_{j} x_{j}\right]\right)\right.
$$

Where $P_{i}=P\left(y_{i}=1 \mid x_{1}, x_{2}, \cdots, x_{k i}\right)$ denotes the probability of $y=1$ occurring ( $y$ is the decision variable representing the event of joining agricultural machinery cooperative management) with the given series of independent variables $x_{1}, x_{2}, \cdots, x_{k i} ; \alpha$ is a constant term, and $\beta_{j}$ represents the regression coefficients for the independent variables. The linear expression for the logistic regression model can be derived:

$$
\operatorname{Ln}\left(\frac{p_{i}}{1-p_{i}}\right)=\alpha+\sum_{j=1}^{k} \beta_{j} x_{j}
$$

With logarithmic transformation, dependent variable in model can be transformed to continuous variables $P$ in the range of $(0,1)$.

\section{B. Variable selection and research hypothesis}

Farmers' participation in agricultural machinery cooperative management is studied, and relevant influence factors are revealed based on questionnaires from farmers. With the literature research and results of existing theoretical analysis, this study select four types of variables to explain farmers' decision-making behaviors and analyze relevant factors, including personal characteristics of the head of household, characteristics of households' farm production and operation, external environment and policy, and characteristics of agricultural machinery cooperation ${ }^{[8]}$.

1) Personal characteristics of the head of household and relevant assumption

Age. It mean the age of the head of households. Age has a greater effect on farmers' participation in agricultural machinery cooperative management. Generally, older farmers will have richer agriculture production experience, but they have increasing inimical emotion to new things and have difficulties in accepting new things; on the contrary, they become more likely to contact new things.

Education level. Education level is positively correlated with farmers' joining in agricultural machinery cooperative management. Farmers with higher education level would have greater willingness to accept new things. As a new thing - agricultural machinery cooperation, farmers with high educational level keep the higher awareness level of agricultural machinery cooperation, and they are more willing to participate in agricultural machinery cooperation.

2) Characteristics of households' farm production and operation, and related assumptions

Farm labor of family. It refers to families' farm labor actually engaged in agricultural production. Here, assuming that more farm labor reduces their dependence on agricultural machinery, and they will have little will to join in agricultural machinery cooperative management.

The proportion of agricultural income in total household income. The greater proportion of agricultural income in total household income make farmers have greater dependence on agricultural production, and they have greater confidence of working on agricultural activities. These farmers are willing to invest more farm labor, material and financial resources to the new cooperative organizations, and they have stronger will to take part in agricultural machinery cooperation.

Whether farmers know of agricultural machinery cooperation. In general, once farmers hear of agricultural machinery cooperation, they will be more concerned about relevant information, understand related policies, laws and regulations, so they have bigger possibility to participate in agricultural machinery cooperation base on their self-conditions.

Whether farmers attend agricultural machinery training. It refers technical training of agricultural mechanization farmers received from government or other organizations. Farmers who receive agricultural machinery training usually have stronger willingness to accept new things, and will be more likely to join in agricultural machinery cooperation; conversely, the possibility is less.

The satisfaction degree with management benefit of farm machinery. Satisfaction degree reflects the recognition degree of farmers to obtained profit benefits of self-managed farm machinery, and it is a key factor in participation decision-making of farm machinery ${ }^{[9]}$. The higher level of satisfaction indicates that management benefit of agricultural machinery is good, and the willingness to join agricultural machinery cooperative management is greater; otherwise the likelihood is less.

3) External environment, policy and corresponding assumptions

Comprehensive degree with policies related to agricultural machinery cooperation. Farmers know more about existing policies to support agricultural machinery cooperation, and they will clearly understand the risk of joining cooperative organizations. The more expected comprehensive degree can make farmers have greater possibility to participate in agricultural machinery cooperation; on the contrary, the possibility is less.

Degree of government support. If government offers more support to agricultural machinery cooperation, it could reduce the risk of farmers taking part in agricultural machinery cooperative management, keep low cost operation, and increase their income. The greater government support will make farmers become more likely to join agricultural machinery cooperation; conversely, the likelihood is less.

Difficult degree of loans. Loose loan conditions can relieve the pressure of farmers, make them more actively participate in agricultural production activities, and they would like to have greater willingness to take part in agricultural machinery cooperative management.

4) Characteristics of agricultural machinery cooperation and relevant assumptions

Influence of neighbors' joining agricultural machinery cooperation on farmers. The behavior choices of neighbors produce a major impact on farmers' agricultural 
production decision-making. In general, the higher proportion of members of agricultural machinery cooperation in neighbors make farmers get greater likelihood to join in agricultural machinery cooperation; otherwise the possibility is less.

Management benefit of agricultural machinery cooperation. More management benefit is what farmers want to get from some production activities. As rational farmers, they will be attracted by higher management benefit of agricultural machinery cooperation; on the contrary, the attraction is less.

Conditions for joining agricultural machinery cooperation. Generally, few basic requirements to take part in agricultural machinery cooperation make farmers be more likely to participate in cooperative organization; conversely, the participation probability is less.

Participation cost of agricultural machinery cooperation. The higher participation cost of agricultural machinery cooperative management often increases farmers' economical burden, affects their normal life, and directly influences their willingness to join in agricultural machinery cooperative management.

Satisfaction degree with local socialized service of agricultural machinery. More expected satisfaction with the local socialized service of agricultural machinery let farmers have less willingness to join agricultural machinery cooperative management; otherwise the willingness is higher.

\section{Data sources}

A questionnaire focusing on the factors influencing the choice of farmers in agricultural machinery cooperative management is designed. The survey assessed four domains, including personal characteristics of the head of household, characteristics of households' farm production and operation, external environment and policy, and characteristics of agricultural machinery cooperation ${ }^{[10-12]}$. Project team receives technical training before investigation and survey. The training content mainly includes definite survey objective, meaning explanation of survey information, explanation of survey methods with specific examples and grasping communication skills with farmers and so on.

Between January and February of 2013, project team members conducted questionnaire survey of farmers household in Shaanxi province, Shanxi province, and Henan province, etc.. The collected questionnaire answers were carefully audited, the questionnaires with incomplete answers were removed, and then a total of 154 effective questionnaires were obtained. Finally, statistical analysis of the relevant information was made, and a database of research information was built.

\section{RESULTS AND DISCUSSION}

The SPSS 16.0 statistical software (SPSS China, Shanghai) is used to conduct the logistic binary regression analysis with the farmers' cross-section data in research. As can be seen in Table I, logistic regression produces a log-likelihood value of 154.288 and a Nagelkerke $\mathrm{R}^{2}$ of 0.342 , and the overall forecast accuracy is $74.3 \%$. So the global fitting degree of model is preferable.

The influence of relevant factors on agricultural machinery cooperative management can be judged by comparing sig values in Table I, and smaller sig values indicates bigger related effect. Analysis results show that main influence factors of farmers' participation in agricultural machinery cooperative management include whether farmers hear of agricultural machinery cooperation, whether farmers receive farm machinery operation training, the proportion of agricultural come in total household income, participation cost of agricultural machinery cooperation, whether neighbors join agricultural machinery cooperation, degree of government support, and satisfaction degree with agricultural machinery management.

(1) Whether farmers know of agricultural machinery cooperation is positively correlated with their participation in agricultural machinery cooperative management.

Whether farmers accept a new thing is often related to their familiar degree with the thing. Farmers who hear of agricultural machinery cooperation usually will pay more attention to relevant information, know about related policies and regulations, and decide whether to participate in agricultural machinery cooperative management according to their own conditions. Based on the statistical data analysis from investigated 154 farmer households, only $59(38 \%)$ households have heard of agricultural machinery cooperation, of which 35 households are willing to join agricultural machinery cooperative management, and it accounts for $59 \%$ of the total households knowing of agricultural machinery cooperation. It indicates that whether farmers hear of agricultural machinery cooperation have a greater impact on their participating in cooperative management organization.

(2) Receiving operation training of agricultural machinery obviously improves farmers' participation willingness of agricultural machinery cooperative management

Operation training of agricultural machinery is an important way to improve the technical level of farm machinery operators, and let them understand modern agricultural technology and equipment. Operation trainees of farm machinery usually are local farmers with agricultural machinery or farmer households interested in agricultural machinery. They want to improve their skills through operation training of agricultural machinery, and can be better engage in agricultural production activities. Most of them have rich experience in agriculture production, and understand the importance of production management organization. In particular, the work amount of go-out agricultural machinery increases in recent years, farmers need to take greater risks when going out alone and operating costs are higher than ever. Cooperative management can achieve resource sharing, risk sharing and easily get government support.

(3) The proportion of agricultural come in household income have positive correlation with their willingness of participating in agricultural machinery cooperative management 
TABLE I. LOGISTIC MODEL RESULTS

\begin{tabular}{|c|c|c|c|c|}
\hline Independent Variable & $B$ & S.E. & Wals & Sig. \\
\hline Age & -0.002 & 0.024 & 0.007 & 0.931 \\
\hline Education level & 0.040 & 0.112 & 0.130 & 0.718 \\
\hline Farm labor of family & 0.391 & 0.260 & 2.257 & 0.133 \\
\hline $\begin{array}{l}\text { The proportion of agricultural } \\
\text { income in total household income }\end{array}$ & 0.625 & 0.263 & 5.650 & 0.017 \\
\hline $\begin{array}{l}\text { Whether farmers know of } \\
\text { agricultural machinery } \\
\text { cooperation }\end{array}$ & -0.733 & 0.474 & 13.370 & 0.000 \\
\hline $\begin{array}{l}\text { Whether farmers attend } \\
\text { agricultural machinery training }\end{array}$ & 2.314 & 0.913 & 6.421 & 0.011 \\
\hline $\begin{array}{l}\text { Comprehension degree with } \\
\text { policies related to agricultural } \\
\text { machinery cooperative } \\
\text { management }\end{array}$ & 0.014 & 0.079 & 0.031 & 0.860 \\
\hline $\begin{array}{l}\text { Impact of government support on } \\
\text { farmers' joining agricultural } \\
\text { machinery cooperation }\end{array}$ & -0.538 & 0.265 & 4.124 & 0.042 \\
\hline $\begin{array}{l}\text { The satisfaction degree with farm } \\
\text { machinery management }\end{array}$ & -0.674 & 0.336 & 4.011 & 0.045 \\
\hline Difficult degree of loans & 0.092 & 0.226 & 0.167 & 0.682 \\
\hline $\begin{array}{l}\text { Effect of neighbors' participation } \\
\text { in agricultural machinery } \\
\text { cooperation on farmers }\end{array}$ & -0.606 & 0.257 & 5.546 & 0.019 \\
\hline $\begin{array}{l}\text { Management benefit of } \\
\text { agricultural machinery }\end{array}$ & 0.118 & 0.265 & 0.198 & 0.657 \\
\hline $\begin{array}{l}\text { Basic requirements to take part in } \\
\text { agricultural machinery } \\
\text { cooperation }\end{array}$ & 0.453 & 0.298 & 2.313 & 0.128 \\
\hline $\begin{array}{l}\text { Satisfaction degree with local } \\
\text { agricultural machinery socialized } \\
\text { service }\end{array}$ & -0.172 & 0.330 & 0.271 & 0.603 \\
\hline $\begin{array}{l}\text { Participation cost of agricultural } \\
\text { machinery cooperation }\end{array}$ & -0.759 & 0.322 & 5.577 & 0.018 \\
\hline Constant term & 0.996 & 2.776 & 0.129 & 0.720 \\
\hline -2Log likelihood & \multicolumn{4}{|c|}{154.288} \\
\hline Nagelkerke $\mathrm{R}^{2}$ & \multicolumn{4}{|c|}{0.342} \\
\hline
\end{tabular}

The proportion of agricultural income in household income is an important indicator reflecting farmers' economic benefit got from agricultural production, and directly affects their initiative in agricultural production. Currently, farmers are engaged more rationally in agricultural production, higher farm income can increase their confidence of participation in agricultural activities, and intend to invest more money into agricultural production. The higher proportion of agricultural income in household income leads to farmers' greater dependence on agricultural production, and they have stronger willingness to participate in agricultural machinery cooperative management. Therefore, the proportion of agricultural come in household income is a key factor influencing farmers' joining cooperative management.
(4) Participation cost of agricultural machinery cooperation is negatively correlated with farmers' participating in agricultural machinery cooperative management

As professional farmers, they often make investment in combination with market changes and their own economic situation when they are engaged in agricultural production, so their investment behavior become more and more cautious. Only when revenue which is earned from cooperative operational organization is higher than income from independent management of agricultural machinery, will participation willingness of farmers be enhanced. Higher participation cost will make farmers not want to invest, because of their ambivalence that they would like to get higher profit but they can not take a risk. Research shows that lower participation cost could achieve more attentions from farmers; on the contrary, the participation possibility is less. Meanwhile, some farmers with good economic foundation would like to join agricultural machinery cooperation, even though the participation cost is higher. As vulnerable group, farmers have low family income, the investment cost of agricultural machinery cooperative management can affect their family living quality. Therefore, only the participation cost of agricultural machinery cooperative management reduces contiguously with fully integration of local economic development status and the actual production needs in rural area, will farmers' burden be lowered and their initiative be improved.

(5) The neighbors' joining agricultural machinery cooperation significantly promotes farmers' participation in agricultural machinery cooperative management

Agricultural machinery cooperative management is a new form of agricultural machinery socialized service, some farmers have hazy understanding on it and remain hesitant out of consideration for avoiding risk. After joining agricultural machinery cooperation, neighbors do not only improve their income but also make promotions for agricultural machinery cooperation, expanding its influence, letting more and more farmers know about it, and contributing to their participation.

(6) Government support has a positive impact on the farmers' taking part in agricultural machinery cooperative management

Government plays an important role in the development process of agricultural machinery cooperation. Farmers hope to get increasing government support, which can really solve the problem that farmers are unwilling to join cooperative organization due to unaffordable technical renovation costs. Greater government support reduces the operating costs of farmers, and helps to improve their willingness to participate in cooperative management. Without government support, farmers will bear huge risk and encounter more resistance when joining in agricultural machinery cooperative management. So government support greatly influences farmers' willingness to participate in agricultural machinery cooperative management, which also implies that government needs to take more responsibility and obligation in driving development process of agricultural machinery cooperation. 
(7) The satisfaction degree with agricultural machinery management positively influences farmers' participation in agricultural machinery cooperative management

Satisfaction degree reflects the recognition degree of farmers to agricultural machinery production and management activities, and it is an important factor in the decision of working on or investing some agricultural machinery activities. The higher level of satisfaction means agricultural machinery management activities can make more income, farmers can own bigger confidence in working on agricultural machinery production and management activities; on the contrary, they will have lower confidence. Research shows that farmers can be more willing to take part in agricultural machinery cooperation with the higher satisfaction level of self-managing farm machinery; otherwise the will is less.

\section{CONCLUSIONS}

In this paper, 154 households are surveyed as research samples. Farmers' participation in agricultural machinery cooperative management and its influencing factors are analyzed based on binary logistic model. Studies showed that there are some important factors affecting their taking part in agricultural machinery cooperative management, such as whether farmers know of agricultural machinery cooperation, operation training experience of agricultural machinery, the proportion of agricultural income in household income, participation cost of agricultural machinery cooperation, whether neighbors join agricultural machinery cooperation, degree of government support, and satisfaction degree with agricultural machinery management. Besides, different factors have different influence on farmers' joining in agricultural machinery cooperative management.

At this stage, government guidance and support play an influential role in encouraging farmers to take part in agricultural machinery cooperative management. Governments should lead farmers to improve their rational awareness of the agricultural machinery cooperation, continue to expand related recognition breadth and depth, and promote efficiency \& benefit of agricultural machinery cooperation by reinforcing technical training strength. Thereby more and more farmers are attracted to attend agricultural cooperative operations, use efficiency and profit of agricultural machinery is enhanced, and socialized service level of agricultural machinery continually improves with increasing income of farmers.

\section{ACKNOWLEDGMENT}

This paper was funded by the MOE (Ministry of education in China) Project of Humanities and Social Sciences(14YJCZH060) and Postdoctoral Science Foundation (2012M510617).

\section{REFERENCES}

[1] Zhu Rui-xiang, Qiu Li-chun. Operation management of agricultural machinery[M]. Beijing: China Agriculture Press, 2009.

[2] Fu Ze-tian, Sun Qi-hou. Current situation and problems in studies on the application of agricultural inputs[J]. Journal of Beijing Agricultural Engineering University, 1992, 12(4): 13-19.

[3] Yang min-li. Technological economics of agricultural mechanization[M]. Beijing: China Agriculture University Press, 2011.

[4] Gao Hai. System deconstruction of farmers cooperatives to promote collective economy[J]. Issues in Agricultural Economy, 2014 (2): 88 94

[5] Yang Yin-sheng, Shu Kun-liang, Guo Hong-peng. Fairness and reciprocity behaviors research on agricultural machinery service organization members[J]. Journal of Agrotechnical, 2008 (6) : $95 \sim 100$.

[6] Xi Ai-hua, Chen Bao-feng. Desire research of agricultural machinery farmers to join agricultural machinery cooperation[J]. Journal of Agrotechnical, 2007 (4) : 109 112.

[7] Wang Ping, Qiu Dao-chi, Li Guang-dong, et al. Based on the wishes of farmers in rural areas intensive land use impact actors[J]. Journal of Agricultural Mechanization Research, 2011(3) :1 $\sim$.

[8] Man Mingjun, Li Tongsheng, 2010. Review of adoption of agricultural technologies, Agricultural economic, 146(1), 80-85. (In Chinese)

[9] Shambhu V.B, Jha S.K. Problems and prospects of agricultural mechanization in Bihar, India[J]. AMA, Agricultural Mechanization in Asia, Africa and Latin America, 2012, 43(3): 55-59.

[10] Laurens K, Noelle A, Cees L. Adaptive management in agricultural innovation systems: The interactions between innovation networks and their environment[J]. Agricultural Systems, 2010(103): 390-400.

[11] Marrit M.V. D. B, Huib H, Joost W, Martin K.V. I, Wang G, Reimund P.R. The impact of increasing farm size and mechanization on rural income and rice production in Zhejiang province, China[J]. Agricultural Systems, 2007(94): 841-850.

[12] Thiago L.R, Marcos M. Material flow determination through agricultural machinery management[J]. Science of Agriculture, 2010, 67(4): 375-383. 